\title{
¿Seasonal Precipitation Influences Streamflow Vulnerability to the 2015 Drought in the Western United States $\mathscr{}$
}

\author{
CHRISTOPHER P. KONRAD \\ U.S. Geological Survey, Tacoma, Washington
}

(Manuscript received 6 June 2018, in final form 7 May 2019)

\begin{abstract}
Streamflow was exceptionally low in the spring and summer of 2015 across much of the western United States because of a regional drought that exploited the sensitivity of both snow- and rain-dominant rivers. Streamflow during 2015 was examined at 324 gauges in the region to assess its response to the amount, form, and seasonal timing of precipitation and the viability of using spatially aggregated, normative models to assess streamflow vulnerability to drought. Seasonal rain and spring snowmelt had the strongest effects on runoff during the same season, but their effects persisted into subsequent seasons as well. Below-normal runoff in the spring of 2015 was pervasive across the region, while distinct seasonal responses were evident in different hydroclimatic settings: January-March (winter) runoff was above normal in most snow-dominant rivers and runoff in all seasons was above normal for much of the desert Southwest. Summer precipitation contributed to summer runoff in both the Pacific Northwest and desert Southwest. A first-order model that presumes runoff is a constant fraction of precipitation (the precipitation elasticity of runoff, $E=1$ ) could be used for assessing and forecasting runoff responses to precipitation deficits across the region, but runoff generally is more vulnerable to drought $(E>1)$ than predicted by a first-order model. Uncertainty in spring and summer precipitation forecasts remain critical issues for forecasting and predicting summer streamflow vulnerability to drought across much of the western United States.
\end{abstract}

\section{Introduction}

Globally droughts pose significant social and ecological threats in part because of limited water availability in rivers and streams (Harding et al. 1995; Heim 2002; Lake 2003; Golladay et al. 2004; Bond et al. 2008; van Dijk et al. 2013; van Lanen et al. 2016). Reduced streamflow during drought in the western United States has wide ranging effects, which can impact society and ecosystems as a result of their severity and spatial extent (Cayan et al. 2010; Dettinger et al. 2015). While seasonal drought is a regular feature of the climate in much of the western United States, changes in the frequency, timing,

¿ Denotes content that is immediately available upon publication as open access.

Supplemental information related to this paper is available at the Journals Online website: https://doi.org/10.1175/JHM-D-180121.s1.

Corresponding author: Christopher P. Konrad, cpkonrad@ usgs.gov magnitude, or spatial extent of droughts would compel adaptive changes in human water use and could further jeopardize aquatic biota and ecosystems because of decreased streamflow (Chang and Bonnette 2016; Gleick 2016). Regional variation of streamflow responses to meteorologic drought is important for assessing vulnerability as part of drought planning and management.

Pervasive drought across the western United States during 2015 provides a case for examining streamflow vulnerability to low spring snowpack, a dry spring, and a dry summer under warm temperatures. Above-normal temperatures and below-normal precipitation enveloped much of the western United States during 2015 (Fosu et al. 2016; Mote et al. 2016; National Centers for Environmental Information 2016; Harpold et al. 2017). January-March 2015 temperatures generally were more than $4^{\circ} \mathrm{C}$ above normal west of $-105^{\circ}$ latitude and belownormal precipitation extended from coastal California and Oregon across to the Sierra Nevada, the Cascades, the Great Basin, and the central Rocky Mountains (National Centers for Environmental Information 2016). Early spring snowpack was exceptionally low (Mote et al. 2016). As the spring progressed, the region

DOI: 10.1175/JHM-D-18-0121.1

For information regarding reuse of this content and general copyright information, consult the AMS Copyright Policy (www.ametsoc.org/ PUBSReuseLicenses). 
of below-normal precipitation shifted north into the Olympic and North Cascade Ranges, and northern Rocky Mountains, while temperatures more than $2^{\circ} \mathrm{C}$ above normal persisted over the Pacific Coast states, Great Basin, and northern Rockies.

The National Weather Service Climate Prediction Center (2018) forecast drought conditions in the spring 2015 , leaving regional water managers to ask: how would streamflow respond to a warm, dry spring, particularly where winter precipitation may have been near normal? The objectives for this analysis are to examine spatial variation in streamflow responses across the western United States to the amount, form, and seasonal timing of precipitation during 2015 and compare approaches for assessing streamflow vulnerability to drought, for example, from long-range (+3 month) quantitative precipitation forecasts.

Streamflow responses to meteorological drought (Heim 2002) are conditioned on the seasonal characteristics of a particular drought and the capacity of river basins to store water, which lead to variation in the runoff response across river systems and among different types drought (Risbey and Entekhabi 1996; Andreadis and Lettenmaier 2006; Safeeq et al. 2014; Stoelzle et al. 2014; Solder et al. 2016; Harpold et al. 2017). In a general vulnerability framework (Turner et al. 2003), streamflow in a river is vulnerable to drought because of the combination of its sensitivity to precipitation and the river's exposure to precipitation deficits. Sensitivity generally indicates how much water is stored in a river basin over time scales longer than the drought and vulnerability represents streamflow responses during a particular drought. The vulnerability of streamflow to drought is essential for predicting long-term impacts from climate change on water resources in the region (Dai 2013; Overpeck 2013; Diffenbaugh et al. 2015; Cooper et al. 2016), but also for near-term forecasting of water availability used to invoke drought management actions such as switching water supplies from surface water to groundwater, curtailing water uses, or leasing water rights to maintain instream flows (Glantz 1982; Seattle Public Utilities 2006; California State Water Resources Control Board 2015; Cronin 2015).

Drought vulnerability assessment must specify a functional form for streamflow responses to precipitation (Safeeq et al. 2014). If the difference between annual precipitation and streamflow is relatively constant year-to-year, streamflow has a zero-order relation to precipitation and streamflow deficits during a drought year can be estimated from precipitation deficits for the year. Alternatively, if the ratio of streamflow to precipitation is relatively constant year-to-year, streamflow has a first-order relation precipitation and streamflow during a drought year scales linearly with precipitation. Methodological bias in vulnerability assessment associated with aridity is a key issue in the western United States because of the range of environments, which spans from deserts to rain forests and can lead to divergent conclusions regarding vulnerability (Andreadis and Lettenmaier 2006; Safeeq et al. 2014). Bias of loworder models may limit their utility for assessing river vulnerability to extreme drought and these limits should be known before applying such model.

\section{Data and analytical methods}

Streamflow responses to precipitation and snowpack during 2015 are examined at 324 streamflow gauges operated by the U.S. Geological Survey on rivers in the contiguous United States draining to the Pacific Ocean or the Great Basin (Konrad et al. 2018; supplemental material S1). Multiple linear regression models are applied to account for the spatial variation in seasonal streamflow as a result of spatial variation in the amount and form of precipitation: autumn is defined as OctoberDecember (OND), winter is January-March (JFM), spring is April-June (AMJ), and summer is July-September (JAS). The results indicate the comparative effects of the form and amount of seasonal precipitation. The vulnerability of streamflow to the 2015 drought is assessed using at-site "normative" models that compare the relations between streamflow and precipitation during 2015 to the relations for a "normal" water year.

\section{a. Datasets}

Gauges were included in the analysis if daily streamflow records were available for at least 10 years from water year (WY) 1981 to WY 2015 and the gauge was active in 2015 (U.S. Geological Survey 2017). Gauges were excluded from the analysis if they are downstream of large dams, extensive diversions, point discharges, or land uses likely to alter streamflow (Falcone 2011, Table 1). More than half of the gauges had 35 years of record. Streamflow was aggregated monthly, seasonally, or annually, divided by the drainage area at the gauge and is reported as runoff $Q(\mathrm{~mm})$.

Mean annual precipitation $P_{N}$ for the current climate normal period, 1981-2010, and monthly mean precipitation during WY 2015 with a 30-s spatial resolution were obtained from PRISM Climate Group (2016) and basin-mean values were calculated in a geographic information system (GIS). Annual snow water equivalent (SWE) on 1 April for 2005-2015 (1-km resolution) was obtained from National Operational Hydrologic Remote Sensing Center (2016) and basin-mean values were calculated in a GIS. 
TABLE 1. Criteria for low-likelihood of anthropogenically altered streamflow. Data from Falcone (2011).

\begin{tabular}{|c|c|}
\hline Basin characteristics & Criteria \\
\hline $\begin{array}{l}\text { Density of wastewater } \\
\text { discharges }\end{array}$ & $<1(1000 \mathrm{~km})^{-2}$ \\
\hline Dam storage & $<20 \mathrm{ML}$ total storage per $\mathrm{km}^{2}$ \\
\hline Impervious cover & $<10 \%$ \\
\hline Road density & $<5 \mathrm{~km} \mathrm{~km}^{-2}$ \\
\hline Cropland & $<20 \%$ cultivated crops \\
\hline Irrigated agriculture & $<5 \%$ irrigated agriculture \\
\hline Canals & $\begin{array}{l}<2 \% \text { of channels (by length) } \\
\text { classified as canals }\end{array}$ \\
\hline Power generation capacity & $<1 \mathrm{MW}$ \\
\hline Riparian cover & $\begin{array}{l}>50 \% \text { of } 100-\mathrm{m} \text { riparian buffer } \\
\text { has natural land cover }\end{array}$ \\
\hline
\end{tabular}

Snowpack and runoff data were not available for the complete climate normal period at all sites, so normal spring snow water equivalent $\left(\mathrm{SWE}_{N}\right)$ is the median annual 1 April SWE for 2005-15 and normal water-year runoff $Q_{N}$ is the median WY runoff for WYs between 1981 and 2015 with available streamflow records. Median rather than mean annual values are used for $\mathrm{SWE}_{N}$ and $Q_{N}$ to reduce the influence of extremely dry or wet years. Median annual SWE and $Q$ generally are less than mean annual values for their respective normal periods as indicated by a cross-site mean absolute difference of $22 \mathrm{~mm}$ for SWE and $39 \mathrm{~mm} \mathrm{yr}^{-1}$ for $Q$ (supplemental material S1). The difference between $Q_{N}$ and the median values for WY 2006-15 (the minimum allowable period of record) at sites with complete records for WY 1981-2015 had a cross-site mean absolute value of $62 \mathrm{~mm} \mathrm{yr}^{-1}$ (supplemental material S2).

Uncertainty in $Q_{N}$ introduced by using different periods of record was evaluated in terms of the standard error of the mean, which is the standard deviation of annual values divided by square root of the number of years of record. The standard error of mean runoff had a cross-site median value of $33 \mathrm{~mm} \mathrm{yr}^{-1}$, the same range $(0-200 \mathrm{~mm})$ for sites with only 10 years of record as the range for sites with 35 years, and was not significantly related to the period of record ( $p>0.75$ of no difference based on a Pearson correlation test). The standard error of the mean for SWE had a cross-site median value of $23 \mathrm{~mm}$. The magnitudes of the standard errors of the mean for runoff and snowpack indicate that additional years of record would only have an appreciable effect on normal values in extremely arid basins.

Significant downward bias in precipitation was evident in wet basins where normal runoff exceeded normal precipitation. Bias is a structural issue for interpolated precipitation data in the western United States because of the lack of high-elevation observations (Henn et al. 2018). Xia (2008) reported bias in PRISM precipitation of $\sim 150 \mathrm{~mm}$ at $600 \mathrm{~mm} \mathrm{yr}^{-1}$. Precipitation values were inflated by a factor of 1.25 presuming the bias scales linearly with precipitation. Adjusted $P_{N}$ was greater than $Q_{N}$ in all basins, but may still underestimate actual precipitation particularly in wet, higher-elevation basins where observational records are limited.

\section{b. Spatial variation in seasonal runoff during the 2015 drought}

Multiple meteorological factors contributed to the 2015 drought in the western United States. The effects of seasonal precipitation and spring snowpack on spatial variation in seasonal runoff were evaluated using multiple linear regression (R Core Team 2018). This approach presumes that cross-site deviation of runoff from its cross-site mean value is related to cross-site variation in precipitation and snowpack. Models were developed separately for distinct hydroclimatic strata to account for potential differences in the responses of seasonal runoff related to gross variation across the region in climatologies, 2015 weather, and dominant runoff mechanisms. The use of strata helps resolve the effects of specific factors that may not be important in all rivers (e.g., snowpack in rain-dominant systems).

The hydroclimatic strata were defined by the seasonal distribution of normal water-year streamflow (Table 2). Five strata with distinct seasonal timing and sources of

TABLE 2. Hydroclimatic strata for analysis of seasonal runoff. Autumn is October-December, winter is January-March, spring is April-June, and summer is July-September.

\begin{tabular}{|c|c|c|c|c|c|c|}
\hline & \multicolumn{4}{|c|}{$\begin{array}{c}\text { Streamflow criteria (fraction of WY } \\
\text { streamflow) }\end{array}$} & \multirow[b]{2}{*}{ Mean basin elevation (m) } & \multirow{2}{*}{$\begin{array}{c}\text { Normal SWE on } 1 \text { April (fraction of } \\
\text { WY precipitation) }\end{array}$} \\
\hline & Autumn & Winter & Spring & Summer & & \\
\hline Cold snow & - & $<0.25$ & $>0.25$ & - & $1390-3180$ & $0.12-0.45$ \\
\hline Snow-rain transition & $<0.5$ & $>0.25$ & $>0.25$ & - & $920-2070$ & $0-0.2$ \\
\hline Autumn-winter rain & $0.25-0.5$ & $<0.25$ & $<0.25$ & - & $250-1860$ & 0.04 \\
\hline Winter rain & - & $>0.5$ & - & $<0.25$ & $320-1550$ & 0 \\
\hline Summer rain & - & - & $<0.25$ & $>0.25$ & $1410-2080$ & 0 \\
\hline
\end{tabular}



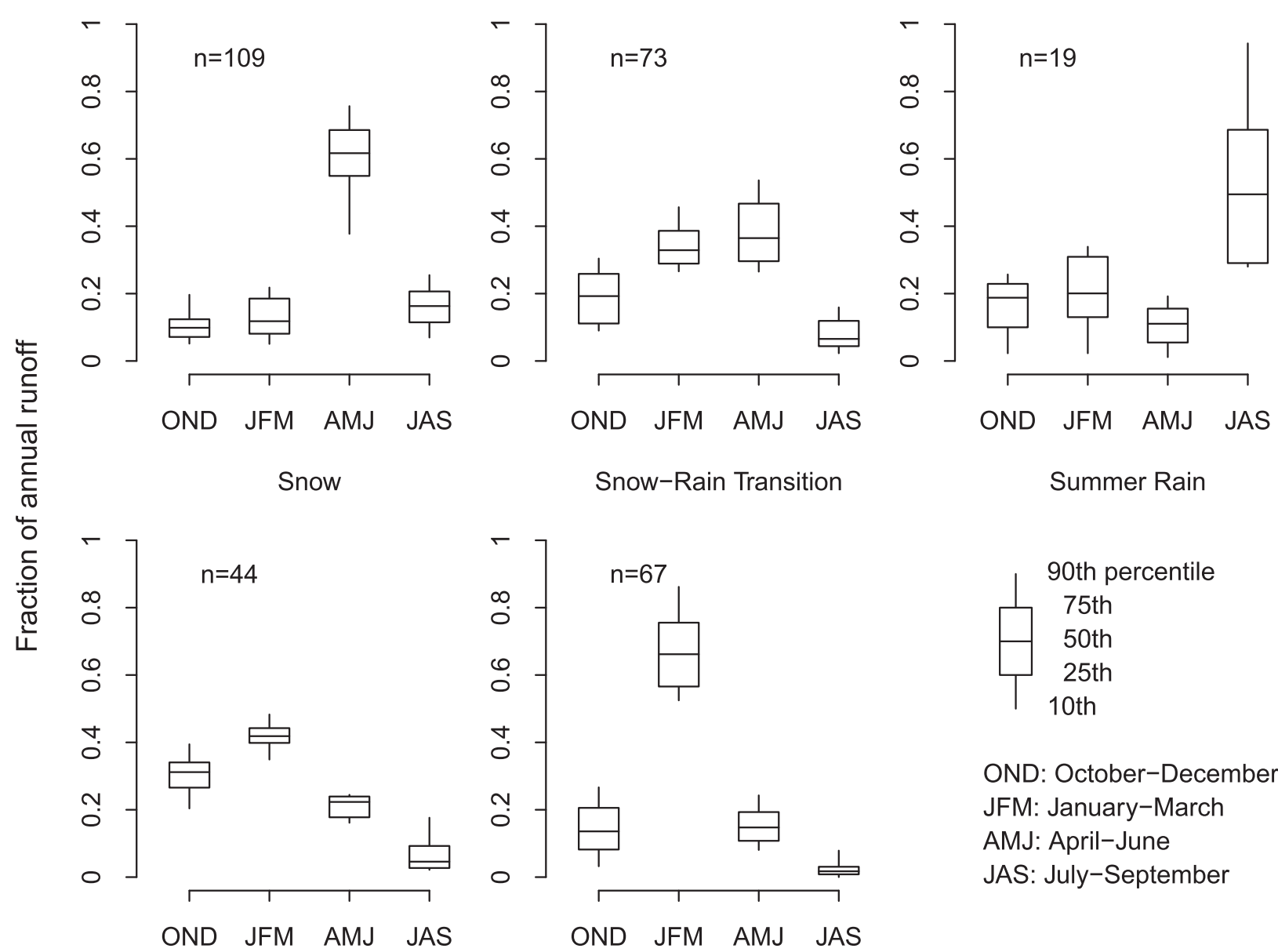

Autumn-Winter Rain

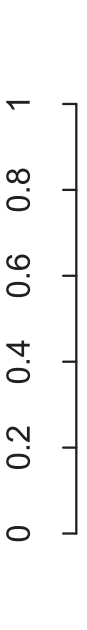

Snow-Rain Transition
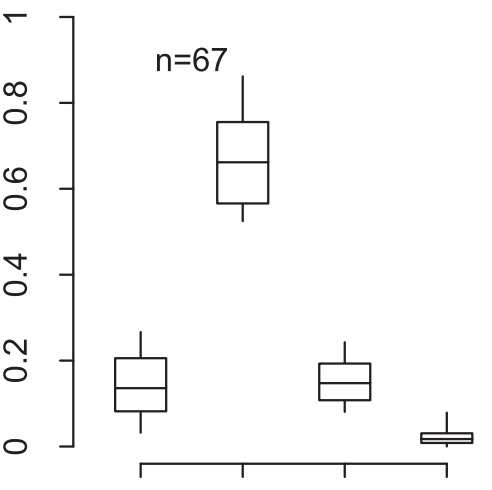

OND JFM AMJ JAS
Summer Rain

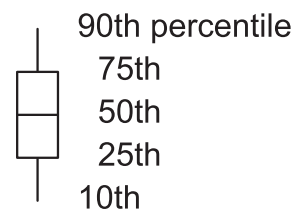

OND: October-December JFM: January-March

AMJ: April-June JAS: July-September

FIG. 1. Distributions of normal seasonal runoff for five hydroclimatic strata in the western United States.

runoff were identified: 1) spring snowmelt, 2) snow-rain transition, which has high winter and spring runoff, 3) winter rain, 4) autumn-winter rain, and 5) summer rain (Fig. 1). Final assignments of rivers were examined by location, mean basin elevation, and normal snow water equivalent on 1 April as a fraction of normal precipitation. The strata are used to summarize differences in seasonal responses to drought, which may be related to either dominant runoff mechanisms or spatial patterns of precipitation during 2015.

For each strata, the effects of seasonal precipitation and snowpack on runoff for winter, spring, and summer 2015 were modeled as

$\hat{Q}_{\mathrm{Win} 2015}=b_{1}+b_{2}\left(P_{\mathrm{AutWin} 2015}-\mathrm{SWE}_{2015}\right)+b_{3} \mathrm{SWE}_{2015}$,

$$
\begin{aligned}
\hat{Q}_{\mathrm{Spr} 2015}= & b_{4}+b_{5}\left(P_{\mathrm{AutWin} 2015}-\mathrm{SWE}_{2015}\right) \\
& +b_{6} \mathrm{SWE}_{2015}+b_{7} P_{\mathrm{Spr} 2015}, \text { and }
\end{aligned}
$$

$$
\begin{aligned}
\hat{Q}_{\text {Sum2015 }}= & b_{8}+b_{9}\left(P_{\text {AutWin2015 }}-\mathrm{SWE}_{2015}\right)+b_{10} \mathrm{SWE}_{2015} \\
& +b_{11} P_{\mathrm{Spr} 2015}+b_{12} P_{\mathrm{Sum} 2015},
\end{aligned}
$$

where $\hat{Q}_{\mathrm{Win} 2015}, \hat{Q}_{\mathrm{Spr} 2015}$, and $\hat{Q}_{\mathrm{Sum} 2015}$ are the respective estimates of runoff for JFM 2015, AMJ 2015, and JAS 2015; $P_{\text {AutWin2015 }}$ is precipitation for OND 2014 and JFM 2015; $P_{\text {Spr2015 }}$ is precipitation for AMJ 2015; and $P_{\text {Sum2015 }}$ is precipitation for JAS 2015 . The term $P_{\text {AutWin2015 }}-\mathrm{SWE}_{2015}$ represents rain or snow that melted for October 2014March 2015. SWE 2015 was not included in models for the three rain-dominant strata (autumn-winter rain, winter rain, and summer rain). All of the terms have consistent units $(\mathrm{mm})$, so coefficient values can be compared directly to assess the effects from a unit of seasonal rain or snowpack.

The coefficients $b_{1}-b_{12}$, in Eqs. (1)-(3) were solved separately for each strata. Twelve sites that had excessive leverage on results (e.g., Cook's distance $>0.5$ ) were not included in the calibration but predictions for 
these sites are included in the model evaluation. Coefficients were retained in final models only when their two-sided probability of equaling zero, $p$, was less than 0.1 . Two models had one parameter each that was marginally significant $(0.05<p<0.1)$. Variance inflation factors were less than 4 for independent variables in each model indicating little effect from multiple colinearity on parameter estimates (Freund and Wilson 1998).

\section{c. Runoff in June and August in rivers with normal WY 2015 precipitation}

The comparative effects of rain and snow on runoff in June and August 2015 independent of water-year precipitation were examined in rivers where WY2015 precipitation was near normal $\left(P_{2015}=P_{N} \pm 10 \%\right)$. Crosssite median June and August 2015 runoff as a fraction of normal is estimated for the snow and snow-rain strata as a conditional, linear function of $\mathrm{SWE}_{2015}$ as a fraction of normal using quantile regression (Koenker et al. 2018) and compared to the distributions of monthly runoff as a fraction of normal for rain-dominant rivers.

\section{d. Normative models for streamflow vulnerability to the 2015 drought}

Normative models that quantify runoff responses to precipitation deficits in relation to "normal" conditions at a site provide a simple approach for assessing the vulnerability of streamflow to drought. The functional form of runoff responses to precipitation deficits in normative models influences how drought vulnerability is represented and, thus, both the assessment and prediction of vulnerability. Two normative models using zero- and first-order relations for runoff responses to precipitation are compared to the responses observed during 2015. Both models are simply at-site empirical relations between normal runoff and precipitation. As such, they can be applied easily in any river with observed precipitation and runoff to assess or predict drought responses presuming the relation would hold for a drought.

For a zero-order relation between streamflow and precipitation, the difference between precipitation and runoff does not vary year-to-year at a site, which is equivalent to assuming that evapotranspiration is constant and any change in precipitation is expressed by an equal change in runoff,

$$
P_{2015}-Q_{2015}=P_{N}-Q_{N},
$$

where $P_{N}-Q_{N}$ represents the normal sensitivity of runoff to precipitation. Runoff during WY 2015 would be estimated from the zero-order normative model as

$$
\hat{Q}_{2015}=Q_{N}-\left(P_{N}-P_{2015}\right) .
$$

The presumption that runoff vulnerability $Q_{N}-Q_{2015}$ equals drought exposure $P_{N}-P_{2015}$ will overestimate streamflow responses to drought where runoff has a less than 1:1 relation to precipitation. The ratio of normal runoff to normal precipitation is an alternative normative model that represents streamflow as a first-order process with respect to precipitation (Milly 1994),

$$
\hat{Q}_{2015}=\frac{Q_{N}}{P_{N}} P_{2015},
$$

and can also be applied to summer streamflow,

$$
\hat{Q}_{\text {Sum } 2015}=\frac{Q_{\text {SumN }}}{P_{N}} P_{2015},
$$

where $Q_{\text {SumN }}$ is normal JAS runoff. The normal runoffprecipitation ratio $Q_{N}: P_{N}$ is a standardized measure of drought sensitivity (i.e., the incremental change in runoff for a unit change in precipitation), which may be acceptable for assessing the runoff response to the forecasted precipitation deficit during a specific drought in rivers where the ratio is relatively constant year to year. This presumption may not hold in dry years when runoff can be a smaller fraction of precipitation than in normal. years. In cases where $Q: P$ varies between normal and dry years, water-year runoff is a nonlinear process with respect to precipitation and the nonlinearity can be important for assessing drought responses in arid basins, dry seasons, and during extremely dry years.

The range of different runoff responses to precipitation from a zero-order model to nonlinear models can be represented by the precipitation elasticity of runoff (Schaake and Chunzhen 1989; Dooge 1992; Sankarasubramanian et al. 2001),

$$
E=\frac{d Q}{d P} \frac{P}{Q}
$$

where $E$ is the precipitation elasticity of runoff, $d P$ is change in precipitation, $d Q$ is change in runoff. Equation (8) presumes that runoff is a differentiable function of precipitation (e.g., continuous with respect to changes in precipitation). For the zero-order response [Eq. (4)], the deviation of runoff in WY 2015 from normal is equal to the deviation of precipitation, so $d Q=d P, E=P / Q$ in Eq. (8), and, thus, $E>1$. For the first-order model [Eq. (6)], runoff as a fraction of normal is equal to precipitation as a fraction of normal,

$$
\frac{Q_{2015}}{Q_{N}}=\frac{P_{2015}}{P_{N}},
$$




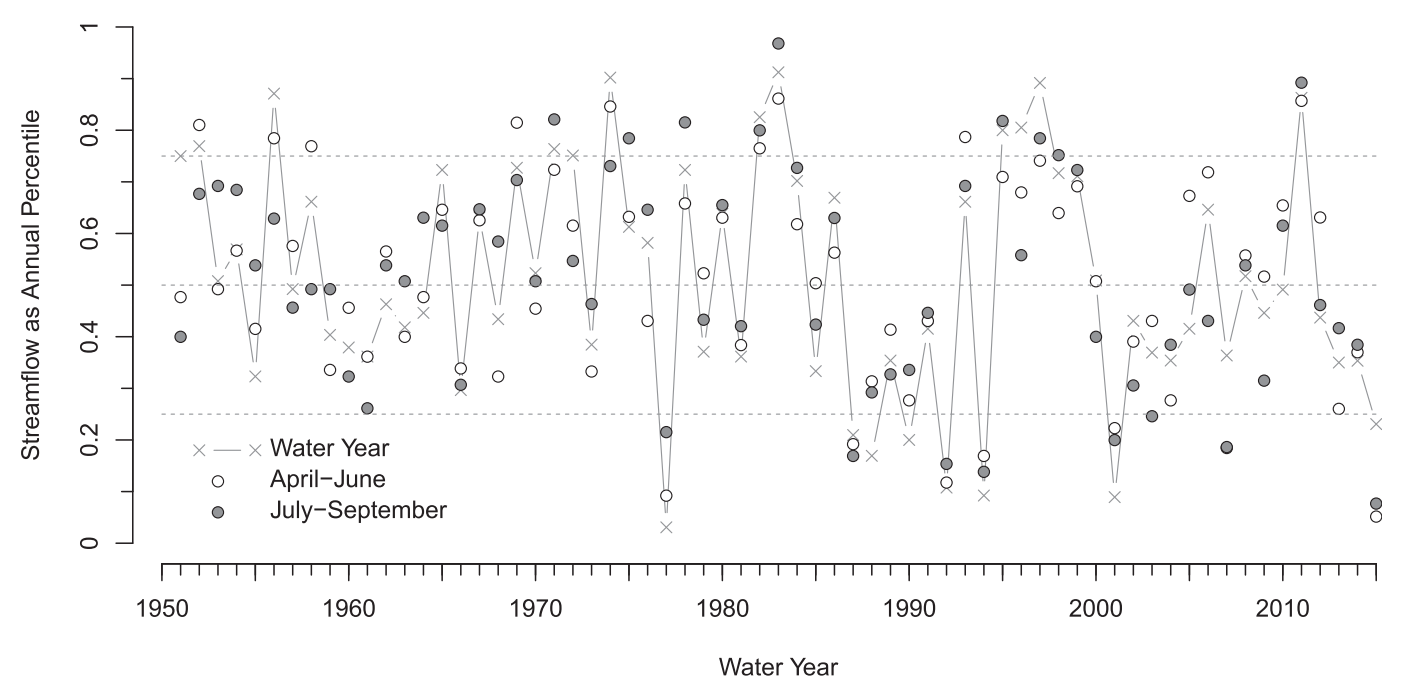

FIG. 2. Median values of annual percentiles of water-year, spring, and summer streamflow for 166 gauges in the western United States with at least 50 years of record.

and, subtraction of 1 from both sides of Eq. (9) gives

$$
\frac{Q_{2015}-Q_{N}}{Q_{N}}=\frac{P_{2015}-P_{N}}{P_{N}}
$$

which can be rearranged as,

$$
\frac{Q_{2015}-Q_{N}}{P_{2015}-P_{N}}=\frac{Q_{N}}{P_{N}}
$$

In this case, the first-order model leads to $d Q / d P=Q_{N} / P_{N}$ and $E=1$ in Eq. (8). The contrasting assumptions of a zeroorder runoff response to precipitation, $E>1$, and a firstorder response, $E=1$, are examined for WY 2015 and summer 2015.

Either normative model [Eqs. (5) and (6)] represents a tractable approach for estimating water-year runoff from quantitative forecasts of water-year precipitation that could be updated seasonally, but neither model is expected to provide precise estimates of runoff during a drought. Summer runoff in particular is likely sensitive to factors other than water-year precipitation (Milly 1994) including evapotranspiration, precipitation from convective storms, and interannual water storage in groundwater, snow, ice, lakes, or reservoirs.

\section{Results}

Water-year streamflow for 2015 was below normal in $87 \%$ of the rivers in this analysis but was not as pervasively low as many recent droughts (e.g., 1977, 1987, 1988, 1990, 1992, 1994, and 2001) when water-year streamflow was less than the 25 th annual percentile for the median site (Fig. 2). The defining characteristic of hydrologic drought in 2015 was the spatial extent of low spring and summer streamflows across the western United States (Fig. 3). Spring 2015 streamflow was at the 5 th percentile of annual values for the median gauge with at least 50 years of record from 1951 to $2015(n=166)$ and summer 2015 streamflow was at the 8th percentile.

Runoff responses to the 2015 drought had distinct seasonal patterns among the hydroclimatic strata that generally converged on below-normal summer runoff across the region (Fig. 4). The winter rain stratum, which extends across California, Arizona, and southern Oregon, had initial responses in winter when runoff was 0.47 of normal for the median site. In contrast, winter runoff was above normal for the median site in snow stratum and normal for the median site in snow-rain transition stratum. The drought resistance of the snow and transitional strata during winter is likely because precipitation fell as rain rather than snow during autumn and winter and snow that melted during the winter in response to warm temperatures. By the spring 2015, runoff was below normal for all strata (Fig. 4) except the summer rain stratum and remained below normal through the summer across the region. Most rivers recovered from the drought by the autumn 2015 when runoff was close to normal for all strata.

\section{a. Effects of the amount and form of seasonal precipitation on spatial variation in seasonal runoff}

Precipitation and its transseasonal storage in snowpack accounted for most of the variation in seasonal runoff during WY 2015 across the western United States with the exception of the summer rain stratum (Table 3). The influence of seasonal precipitation and spring 


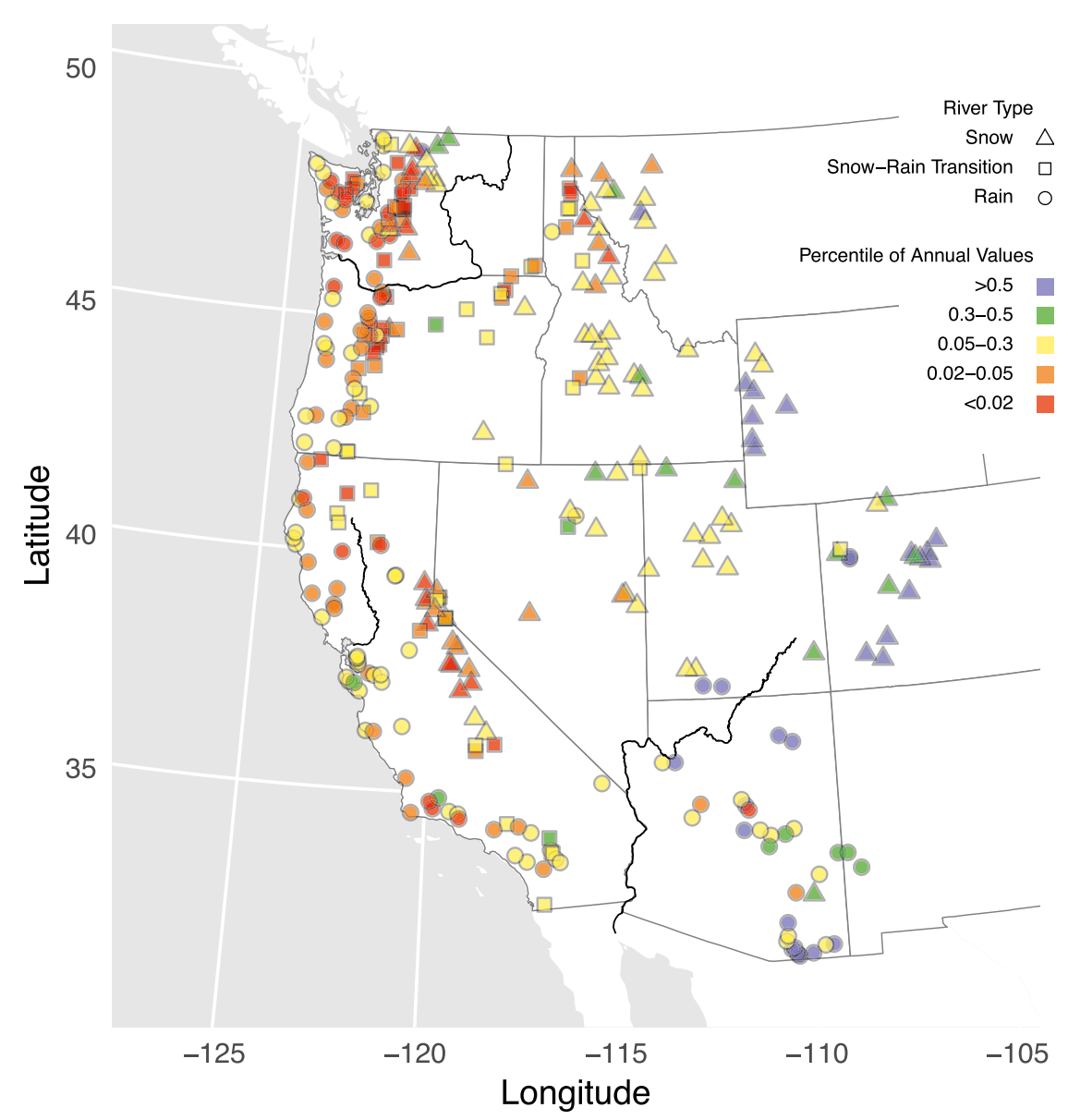

FIG. 3. Runoff for June-August 2015 as a percentile of annual values for 1981-2015.

snowpack diminish over time with the strongest effects on runoff in the same season. Winter runoff had significant effects from autumn-winter rain and snowmelt in all strata (coefficients ranging from 0.25 to 0.36 and $R^{2}$ ranging from 0.88 to 0.91 except the summer rain stratum, where the coefficient was 0.083 and $R^{2}=0.29$ ). All of the strata had significant negative intercepts indicating a minimum amount of precipitation needed before runoff would be generated.

The spring runoff models had $R^{2}$ ranging from 0.79 to 0.81 except for the summer rain stratum $\left(R^{2}=0.44\right)$ (Table 3). Spring rain had significant effects on spring runoff (coefficients ranging from 0.043 to 0.46 ), which were stronger than the effect of autumn-winter rain in all strata (coefficients ranging from 0.0022 to 0.12 ). Spring runoff in the snow and snow-rain transition strata was related most strongly to spring snowpack ( 0.65 and 0.66 , respectively), but winter and spring rain also had significant effects.

Summer runoff models generally accounted for less of the variation in runoff $\left(R^{2}=0.31-0.72\right)$ than in the other seasons (Table 3 ). Winter rain had a small but significant effect $(0.003-0.07)$ on summer runoff in all strata. Summer rain had the strongest effect but it was only significant for snow (0.17) and autumn-winter rain (0.18) strata, which may be a result of convective storms during summer over high-elevation basins. Spring rain was significant for summer runoff in the snow (0.2), winter rain (0.031), and summer rain (0.054) strata. Spring snowpack only had a significant effect $(0.13)$ on summer runoff in the snow stratum.

\section{b. June and August runoff in rivers with near-normal precipitation for water year 2015}

While runoff as a fraction of normal in June and August 2015 was significantly correlated with WY 2015 precipitation as fraction of normal (Kendall rank correlation of 0.30 and 0.26 , respectively, $p<0.001$ ), the correlation does not hold for rivers with near-normal WY 2015 precipitation (indicated by boxes in Figs. 5a,b). Thus, basins with near-normal precipitation in WY 2015, $P_{2015}=P_{N} \pm 10 \%$, present an opportunity to examine late spring and summer streamflow responses to the form of precipitation (snow or rain) without the confounding influence of water-year precipitation deficits. 

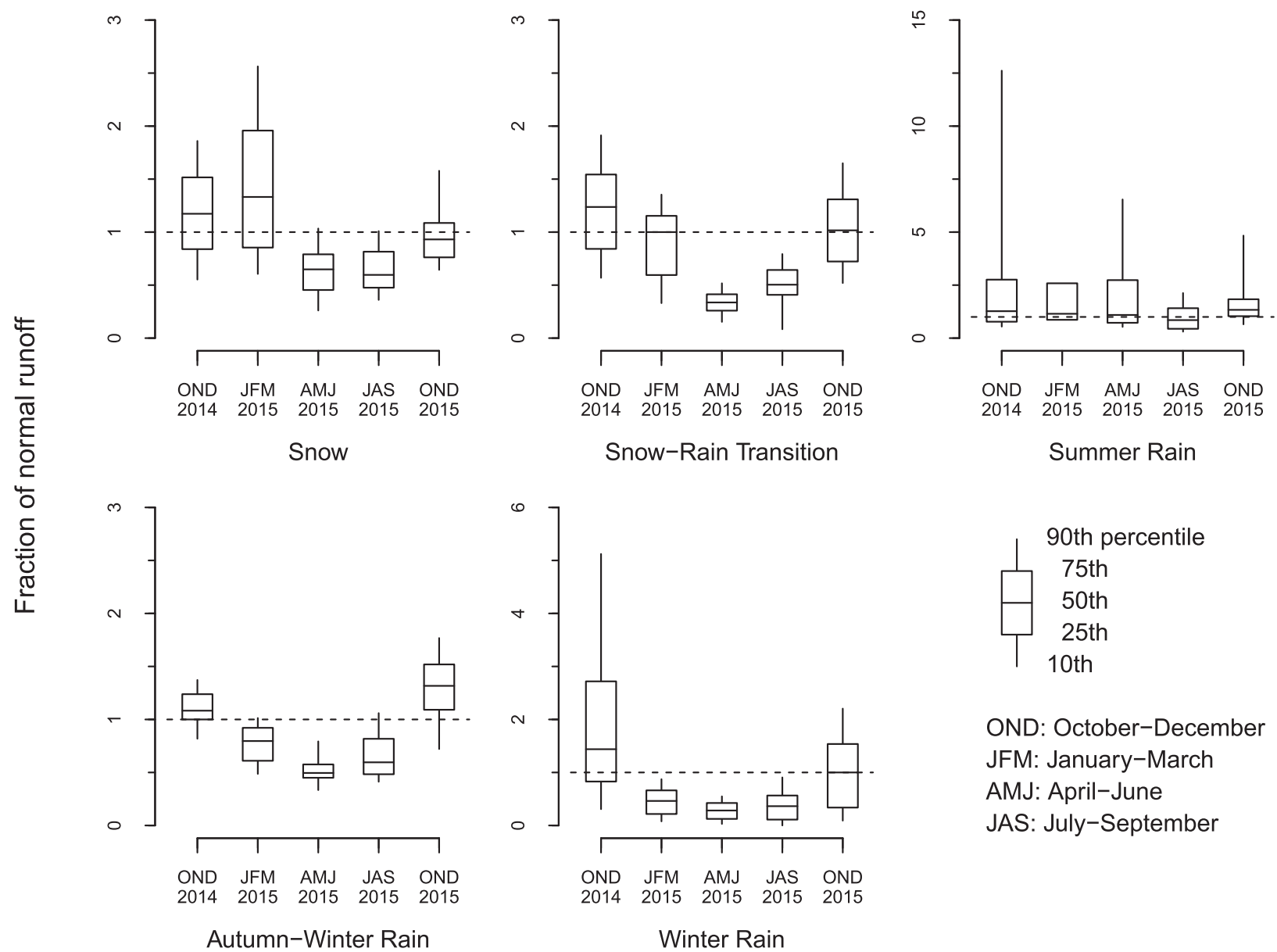

OND: October-December JFM: January-March AMJ: April-June JAS: July-September

FIG. 4. Distributions of seasonal runoff for 2015 as a fraction of normal for five hydroclimatic strata in the western United States.

In rain-dominant rivers with near-normal WY 2015 precipitation, runoff as a fraction of normal in June and August 2015 had cross-river median values of 0.77 and 0.69 respectively (Figs. 5c,d). In comparison, June and August 2015 runoff in snow-dominant and transitional rivers with near-normal WY 2015 precipitation had median values of 0.56 and 0.63 of normal respectively. Snowpack had a significant effect on the variation in median June runoff as a fraction of normal across snow-dominant and transitional rivers, $Q_{\text {June2015 }} / Q_{\text {JuneN }} 0.23+0.80 \mathrm{SWE}_{2015} / \mathrm{SWE}_{N}$ (95\% CI for the SWE coefficient of 0.71-0.99) but the effect was not significant in August when median runoff as fraction of normal August runoff was $Q_{\text {August2015 }} / Q_{\text {AugustN }} 0.55+$ $0.19 \mathrm{SWE}_{2015} / \mathrm{SWE}_{N}(95 \%$ CI for the SWE coefficient from -0.04 to 0.25 ).

Runoff deficits were common during August in both snow- and rain-dominant rivers even where water-year precipitation was near normal. While snowpack had a significant effect on median June runoff, its effect on median August runoff was not significant. Likewise, August runoff deficits in snow and snow-rain transition rivers were not more severe as a fraction of normal than the deficits in rain-dominant rivers where water-year precipitation was close to normal.

\section{c. Vulnerability of runoff to drought}

The zero- and first-order normative models for streamflow responses to precipitation lead to divergent assessments of drought vulnerability. For the zero-order model, the difference between precipitation and runoff for WY 2015, $P_{2015}-Q_{2015}$, is well correlated (Pearson correlation coefficient 0.85 ) but generally less than the difference for a normal water year $P_{N}-Q_{N}$ (Fig. 6a). Equivalently, the runoff deficit $Q_{N}-Q_{2015}$, was less than the precipitation deficits $P_{N}-P_{2015}$ across most sites (Fig. 6b), so Eq. (5) generally underestimates runoff for WY 2015 (median residual of $121 \mathrm{~mm}$, Table 4). As a result, a zero-order model would predict greater drought vulnerability of water-year runoff than was observed in WY 2015.

The first-order model of runoff as a constant fraction of precipitation [Eq. (6)] provides more accurate and 
TABLE 3. Summary of linear regression models for seasonal runoff during WY 2015. Autumn is October-December 2014, winter is January-March 2015, spring is April-June 2015, and summer is July-September 2015

\begin{tabular}{|c|c|c|c|c|c|c|c|c|}
\hline & \multirow[b]{3}{*}{$\begin{array}{l}\text { Mean runoff } \\
(\mathrm{mm})\end{array}$} & \multicolumn{5}{|c|}{ Model parameters } & \multirow[b]{3}{*}{$\begin{array}{c}\text { Residual } \\
\text { standard } \\
\text { error }(\mathrm{mm})\end{array}$} & \multirow[b]{3}{*}{$R^{2}$} \\
\hline & & \multirow[b]{2}{*}{$\begin{array}{l}\text { Intercept } \\
(\mathrm{mm})\end{array}$} & \multicolumn{3}{|c|}{ Rain } & \multirow[b]{2}{*}{$\begin{array}{l}\text { SWE } \\
(\mathrm{mm})^{\mathrm{a}}\end{array}$} & & \\
\hline & & & $\begin{array}{l}\text { Autumn-winter } \\
\qquad(\mathrm{mm})\end{array}$ & $\begin{array}{l}\text { Spring } \\
(\mathrm{mm})\end{array}$ & $\begin{array}{l}\text { Summer } \\
(\mathrm{mm})\end{array}$ & & & \\
\hline \multicolumn{9}{|c|}{ Winter runoff } \\
\hline Snow & 114 & -57 & 0.32 & - & - & - & 46.8 & 0.92 \\
\hline Snow-rain transition & 295 & -91 & 0.32 & - & - & - & 93.9 & 0.91 \\
\hline Autumn-winter rain & 491 & -164 & 0.36 & - & - & - & 122 & 0.90 \\
\hline Winter rain & 119 & -85 & 0.25 & - & - & - & 56.2 & 0.88 \\
\hline Summer rain & 4.0 & -13 & 0.083 & - & - & - & 4.9 & 0.29 \\
\hline \multicolumn{9}{|c|}{ Spring runoff } \\
\hline Snow & 184 & -84 & 0.12 & 0.46 & - & 0.65 & 71.5 & 0.79 \\
\hline Snow-rain transition & 100 & -36 & 0.077 & 0.21 & - & $0.66^{\mathrm{b}}$ & 37.3 & 0.84 \\
\hline Autumn-winter rain & 144 & -64 & 0.081 & 0.29 & - & - & 40.0 & 0.85 \\
\hline Winter rain & 23 & -28 & 0.035 & 0.21 & - & - & 15.5 & 0.80 \\
\hline Summer rain & 1.3 & -6.3 & 0.022 & 0.043 & - & - & 1.3 & 0.44 \\
\hline \multicolumn{9}{|c|}{ Summer runoff } \\
\hline Snow & 54 & -71 & 0.070 & 0.20 & 0.17 & 0.13 & 42.2 & 0.64 \\
\hline Snow-rain transition & 36 & -8.0 & 0.036 & - & - & - & 31.2 & 0.52 \\
\hline Autumn-winter rain & 43 & -35 & 0.025 & - & 0.18 & - & 24.4 & 0.72 \\
\hline Winter rain & 3.4 & -2.6 & 0.003 & 0.031 & - & - & 3.6 & 0.47 \\
\hline Summer rain & 3.4 & -8.7 & 0.040 & $0.054^{\mathrm{b}}$ & - & - & 2.6 & 0.31 \\
\hline
\end{tabular}

${ }^{\text {a }}$ SWE for 1 April 2015.

${ }^{\mathrm{b}}$ Probability that coefficient is equal to zero is $0.05-0.1$.

less biased estimates of runoff for WY 2015 than the zero-order model [Eq. (5); Table 4]. The performance of the first-order model reflects ratios of runoff-toprecipitation for WY $2015 Q_{2015}: P_{2015}$ that are close to values for normal water years: the median at-site difference between $Q_{2015}: P_{2015}$ and $Q_{N}: P_{N}$ is only $9 \%$ of $Q_{N}: P_{N}$ (Fig. 6a). Runoff-to-precipitation ratios for WY 2015, however, were lower than normal for most rivers: the median precipitation elasticity of runoff in WY 2015 was $E_{2015}=1.3$. The highest values of $E_{2015}$, indicating the ratio $Q_{2015}: P_{2015}$ diverged from $Q_{N}: P_{N}$ and extreme vulnerability to drought, were in some arid rivers (lower left, Fig. 6a) where $Q_{N}: P_{N}<0.3$. Forecasting or predicting drought responses in these rivers would require a model that accommodates $E>1$ rather than $Q_{N}: P_{N}$.

The ratio of summer runoff to WY precipitation was generally less in 2015 than in normal years (Fig. 6b). For the median site, $Q_{\text {Sum2015 }}: P_{2015}=0.68 Q_{\text {SumN }}: P_{N}$ and $E_{\text {summer2015 }}=2.3$. Thus, the first-order normative model consistently overpredicts summer runoff (Table 4). Summer runoff in snow-dominant rivers generally was more resistant to drought than other rivers, $E_{\text {summer2015 }}=1.7$ (Fig. 6b). In contrast, summer runoff for rain-dominant rivers in arid basins, where summer runoff normally is $<1 \%$ of water-year precipitation
(Fig. 6b), was particularly vulnerable to the 2015 drought, $Q_{2015}: P_{2015} \ll Q_{N}: P_{N}$.

\section{Discussion}

Across the western United States, streamflow during the spring and summer of 2015 generally was lower than in any drought over the last half century (Fig. 2). The spatial extent of spring runoff deficits (Fig. 3) resulted from the combination of below-normal precipitation in winter and spring that affected both snow- and raindominant rivers. Paradoxically, most snow-dominant rivers had more winter runoff than normal (1.6 for the median river, Fig. 4) because of precipitation falling as rain during the autumn and winter and midwinter snowmelt. Overall, however, low snowpack and the lack of spring rainfall led to lower spring and early summer runoff even in rivers with near-normal WY 2015 precipitation (Fig. 5c).

Runoff during the spring and summer 2015 was below normal in most rivers regardless of their hydroclimatic strata (Fig. 4). Above-normal temperatures and a corresponding increase in potential evapotranspiration may have contributed to below-normal spring and summer streamflow (Das et al. 2011; Williams et al. 2015; Diffenbaugh et al. 2015; Marlier et al. 2017) particularly 

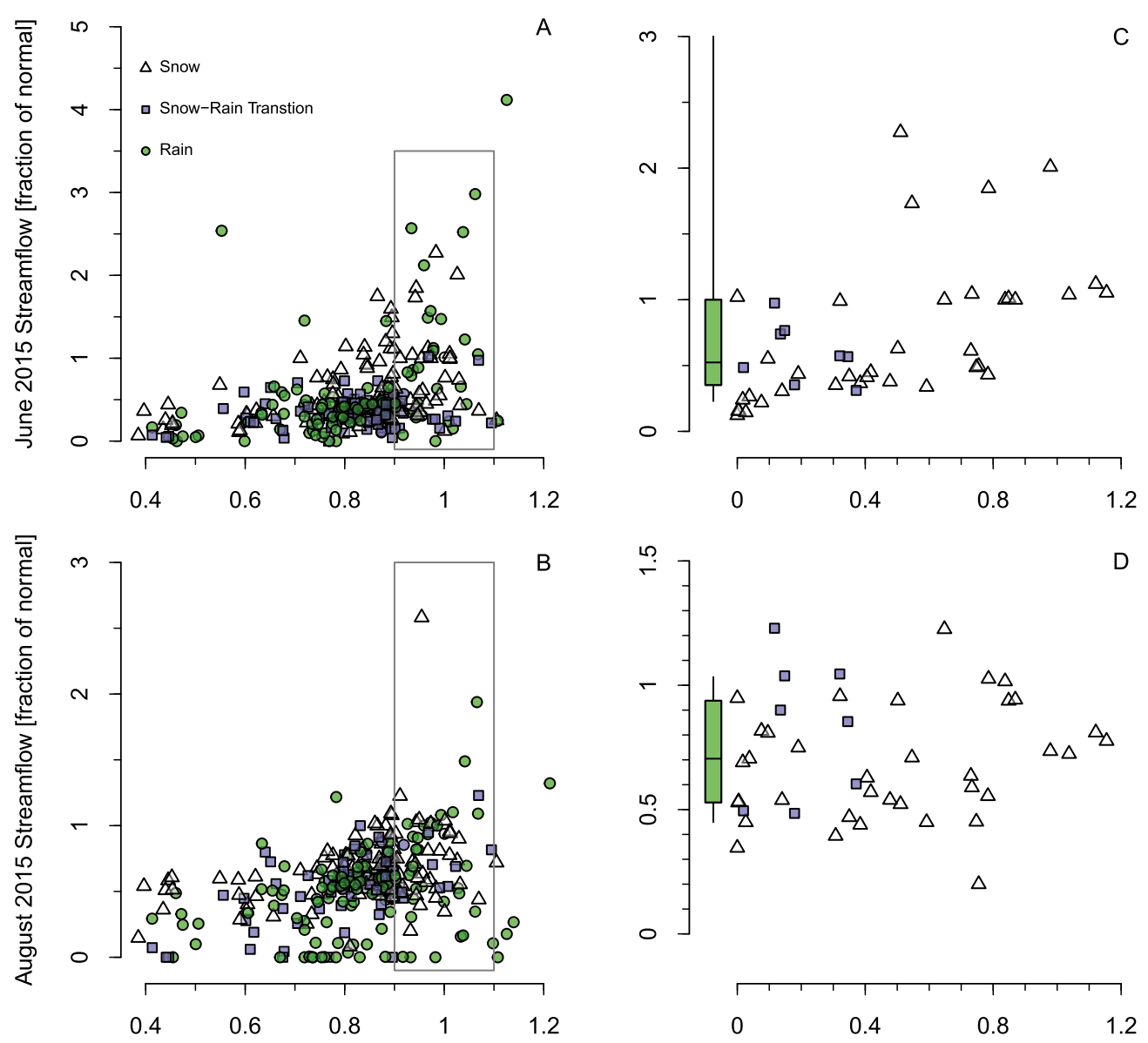

Water Year 2015 Precipitation [fraction of normal] 1 April 2015 Snow-Water Equivalent [fraction of normal]

FIG. 5. WY 2015 precipitation with (a) June 2015 and (b) August 2015 runoff and SWE on 1 April 2015 with monthly runoff in rivers with near-normal WY 2015 precipitation for (c) June 2015 and (d) August 2015. Rectangles in (a) and (b) comprise rivers where WY 2015 precipitation was near normal ( $\pm 10 \%)$. Box and whiskers represent the 10th, 25th, 50th, 75th, and 90th percentiles of monthly runoff for rain-dominant sites.

in rivers with near-normal water-year precipitation (Figs. 5c,d), but precipitation deficits still had significant effects on spring and summer runoff (Mao et al. 2015; Cooper et al. 2016; Table 3). While, snow-dominant rivers were vulnerable to the 2015 drought because of low spring snowpack, snow-dominant rivers were not more vulnerable than rain-dominant rivers (Fig. 4) because of the pervasively dry spring.

The seasonal distribution of precipitation across the western United States (Cayan 1996; Mock 1996) produces distinct provinces where summer streamflow is vulnerable to particular types of drought. In provinces where summer typically is dry (e.g., coastal California), the vulnerability of summer streamflow primarily is controlled by exposure to low precipitation during winter. In contrast, both the Pacific Northwest and desert Southwest can receive substantial precipitation in the spring or summer. In these provinces, water-year precipitation is an incomplete measure of drought exposure for summer runoff, so accurate forecasts of spring and summer precipitation are necessary for forecasting runoff during a drought. Likewise, summer runoff responses to climate change will depends on accurate prediction of changes in seasonal precipitation.

The warm and dry winter and spring in 2015 across the western United States were linked through common control by sea surface temperature and atmospheric flow (Bond et al. 2015; Fosu et al. 2016; Mote et al. 2016), but winter and spring meteorology is not strongly coupled across the western United States in all years (Cayan et al. 1998). The strength of this coupling depends on the persistence of sea surface temperatures and atmospheric flow promoting warm and dry conditions from late fall through the spring (Dettinger 2013; Seager et al. 2015), which is critical for forecasting hydrologic droughts that encompass the region (Glantz 1982; Wood et al. 2015; 

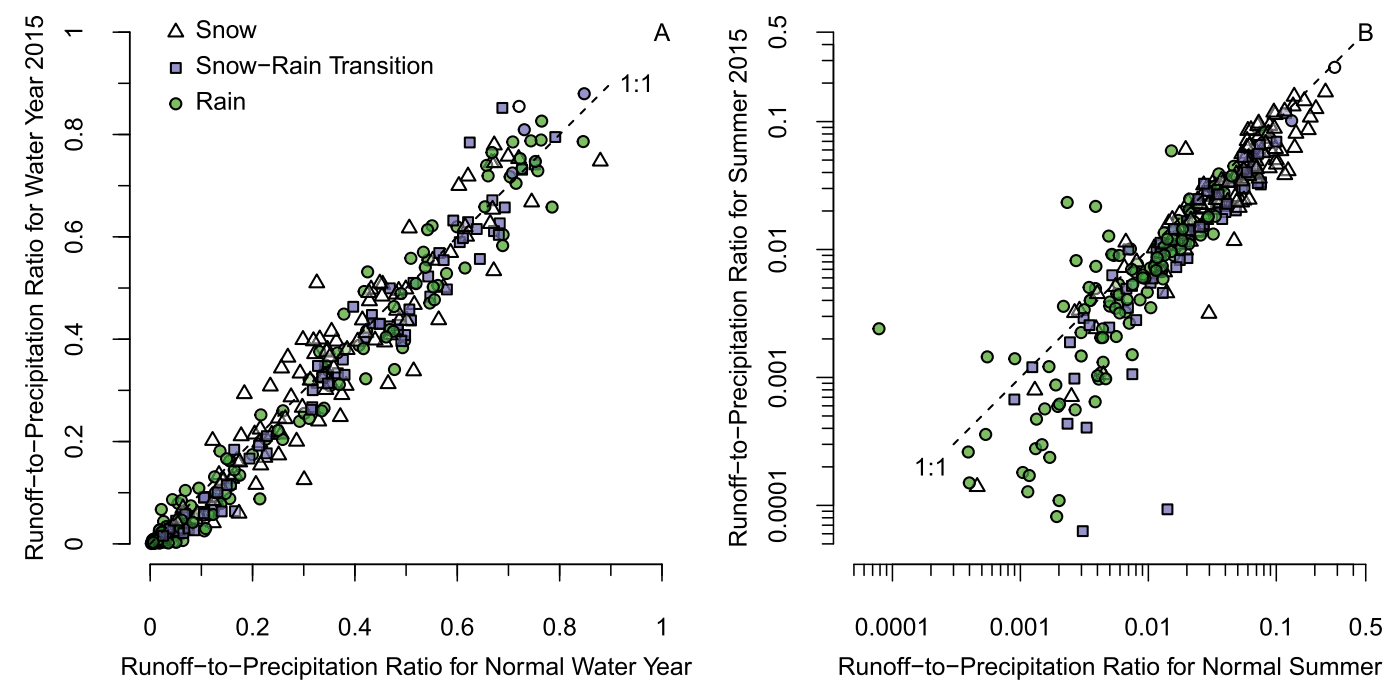

FIG. 6. Ratios of (a) WY runoff to WY precipitation and (b) July-September runoff to WY precipitation. The 1:1 line represents a precipitation elasticity of runoff, $E=1$.

Newman et al. 2016) and predicting their frequency in the future (Dettinger et al. 2011; Dai 2013). Forecasting summer hydrologic drought, however, can focus on precipitation for specific seasons that vary by province such as winter for the Sierra Nevada in California (Diffenbaugh et al. 2015; Mao et al. 2015), winter and spring in the Pacific Northwest (Glantz 1982; Cooper et al. 2016), and summer in the desert Southwest (Adams and Comrie 1997; Cayan et al. 1998).

Years with lower snowpack in the spring are likely to become more frequent across the western United States (Mote et al. 2005; Barnett et al. 2008), so spring and summer precipitation remain key uncertainties for predicting either summer runoff vulnerability to drought and the frequency, magnitude, and extent of extensive hydrologic droughts in the western United States. WY 2015 provides only weak evidence about the response of summer streamflow to variation in spring precipitation [Eq. (4), Table 3], which was pervasively low across the region. Rain-dominant rivers with near-normal precipitation typically had below-normal summer runoff in 2015 (Fig. 5) and summer 2015 runoff was generally a smaller fraction of water-year precipitation than in normal years in most rivers (Fig. 6b). The vulnerability of summer streamflow in snow-dominant rivers during a year with low snowpack but a wet spring remains an open and relevant question for assessing potential impacts from climate change in the western United States (Glantz 1982; Dettinger 2013; Cooper et al. 2016; Easterling et al. 2017; Gershunov et al. 2017).

The first-order model based on the normal ratio of runoff to precipitation $Q_{N}: P_{N}$ provides a relatively robust approach for assessing streamflow responses to drought across the region for the water year (Fig. 6a). The nonlinear relation between runoff and precipitation represented by $E>1$ compels the application of an alternative model for more accurate forecasts of streamflow particularly for arid basins, dry seasons, or dry years. In these contexts, runoff deficits as a fraction of normal amplify precipitation deficits as a fraction of normal [Eq. (8)] because runoff is a smaller fraction of precipitation during drought years compared to normal years. Assessments employing a first-order model will indicate increasing vulnerability (lower $Q: P$ ) with aridity. A zero-order model will result in the opposite assessment of vulnerability: humid basins have the largest runoff deficits with a physical dimension of depth. Either a linear regression model, which combines a zero-order

TABLE 4. Comparison of model errors.

\begin{tabular}{llcc}
\hline \hline \multicolumn{1}{c}{ Model } & Equation & $\begin{array}{c}\text { Residual standard } \\
\text { error (mm) }\end{array}$ & $\begin{array}{c}\text { Median residual } \\
(\mathrm{mm})\end{array}$ \\
\hline Zero-order, normative model for WY 2015 runoff & Eq. (5) & 234 & 121 \\
First-order, normative model for WY 2015 runoff & Eq. (6) & 112 & -11 \\
Multiple linear regression for summer 2015 runoff & Eq. (3) & 45 & -0.6 \\
First-order normative model for summer 2015 runoff & Eq. (7) & 40 & -3.7 \\
\hline
\end{tabular}


term (the intercept) with a first-order term (the slope), or a higher-order model would be necessary for $E>1$ and, thus maybe needed for streamflow forecasts in arid basins, dry seasons, or dry years.

\section{Conclusions}

Streamflow was exceptionally low in the spring and summer of 2015 across much of the western United States because of the combination of low precipitation and snowpack that exploited the sensitivity of both raindominant and snow-dominant basins. Streamflow responses to the 2015 drought were generally consistent with a first-order model based on the at-site ratio of normal runoff to normal water-year precipitation, which is equivalent to a precipitation elasticity of runoff, $E=1$. Greater vulnerability (lower runoff and $E>1$ ) was indicated by bias in the model particularly in arid basins and during summer. A model that accommodates $E>1$ is necessary for more accurate assessment of streamflow responses to extreme drought. Summer streamflow for much of the western United States depends on spring and summer precipitation, so prediction of streamflow responses during drought will depend on accurate forecasts of spring and summer precipitation. While lower spring snowpack in response to climate change will likely to reduce late spring and early summer runoff from snowmelt, late summer streamflow in many rivers will depend on changes in spring and summer precipitation.

Acknowledgments. U.S. Geological Survey and the National Oceanic and Atmospheric Administration National Integrated Drought Information System funded this investigation. My colleagues Jim Bartolino, Tana Haluska, Theresa Olsen, Dina Selah, and Kara Watson with the U.S. Geological Survey helped compile data used in the analysis.

\section{REFERENCES}

Adams, D., and A. Comrie, 1997: The North American Monsoon. Bull. Amer. Meteor. Soc., 78, 2197-2213, https://doi.org/ 10.1175/1520-0477(1997)078<2197:TNAM >2.0.CO;2.

Andreadis, K., and D. P. Lettenmaier, 2006: Trends in 20th century drought over the continental United States. Geophys. Res. Lett., 33, L10403, https://doi.org/10.1029/2006GL025711.

Barnett, T., and Coauthors, 2008: Human-induced changes in the hydrology of the western United States. Science, 319, 1080-1083, https://doi.org/10.1126/science.1152538.

Bond, N., P. Lake, and A. Arthington, 2008: The impacts of drought on freshwater ecosystems: an Australian perspective. Hydrobiologia, 600, 3-16, https://doi.org/10.1007/s10750-008-9326-z.

- M. Cronin, H. Freeland, and N. Mantua, 2015: Causes and impacts of the 2014 warm anomaly in the NE Pacific. Geophys. Res. Lett., 42, 3414-3420, https://doi.org/10.1002/2015GL063306.
California State Water Resources Control Board, 2015: Water Right Curtailment Update. California Department of Environmental Protection, accessed on accessed on 26 December 2017, https://www.waterboards.ca.gov/press_room/press_releases/ 2015/pr062615_wr_curtailment_update.pdf.

Cayan, D., 1996: Interannual climate variability and snowpack in the western United States. J. Climate, 9, 928-948, https://doi.org/ 10.1175/1520-0442(1996)009<0928:ICVASI >2.0.CO;2.

- M. Dettinger, H. Diaz, and N. Graham, 1998: Decadal variability of precipitation over western North America. J. Climate, 11, 3148-3166, https://doi.org/10.1175/1520-0442(1998) 011<3148:DVOPOW >2.0.CO;2.

— T. Tas, D. Pierce, T. Barnett, M. Tyree, and A. Gershunov, 2010: Future dryness in the southwest US the hydrology of the early 21 st century drought. Proc. Natl. Acad. Sci. USA, 107, 21 271-21 276, https://doi.org/10.1073/pnas.0912391107.

Chang, H., and M. Bonnette, 2016: Climate change and waterrelated ecosystem services: Impacts of drought in California, USA. Ecosyst. Health Sustain., 2, https://doi.org/10.1002/ ehs 2.1254.

Climate Prediction Center, 2018: U.S. seasonal drought outlook. Accessed 5 April 2018, https://www.cpc.ncep.noaa.gov/products/ expert_assessment/sdo_archive/2015/sdo_jja15.png.

Cooper, M., A. Nolin, and M. Safeeq, 2016: Testing the recent snow drought as an analog for climate warming sensitivity of Cascades snowpacks. Environ. Res. Lett., 11, 084009, https://doi.org/ 10.1088/1748-9326/11/8/084009.

Cronin, A., 2015: Flow restoration during severe drought: Washington enters uncharted territory. The Water Report, No. 139, The Water Report, Eugene, OR, 1-6, http://thewaterreport.com/.

Dai, A., 2013: Increasing drought under global warming in observations and models. Nat. Climate Change, 3, 52-58, https:// doi.org/10.1038/nclimate1633.

Das, T., D. Pierce, D. Cayan, J. Vano, and D. Lettenmaier, 2011: The importance of warm season warming to western U.S. streamflow changes. Geophys. Res. Lett., 38, L23403, https:// doi.org/10.1029/2011GL049660.

Dettinger, M., 2013: Atmospheric rivers as drought busters on the U.S. West Coast. J. Hydrometeor., 14, 1721-1732, https:// doi.org/10.1175/JHM-D-13-02.1.

—, F. Ralph, T. Das, P. Neiman, and D. Cayan, 2011: Atmospheric rivers, floods and the water resources of California. Water, 3, 445-478, https://doi.org/10.3390/w3020445.

_ B. Udall, and A. Georgakakos, 2015: Western water and climate change. Ecol. Appl., 25, 2069-2093, https://doi.org/ 10.1890/15-0938.1.

Diffenbaugh, N., D. Swain, and D. Touma, 2015: Anthropogenic warming has increased drought risk in California. Proc. Natl. Acad. Sci. USA, 112, 3931-3936, https://doi.org/10.1073/ pnas.1422385112.

Dooge, J., 1992: Sensitivity of runoff to climate change: A Hortonian approach. Bull. Amer. Meteor. Soc., 73, 2013-2024, https://doi.org/10.1175/1520-0477(1992)073<2013:SORTCC > 2.0.CO;2.

Easterling, D., and Coauthors, 2017: Precipitation change in the United States. Climate Science Special Report: Fourth National Climate Assessment, D. Wuebbles et al., Eds., Vol. 1, U.S. Global Change Research Program, 207-230, https:// doi.org/10.7930/J0H993CC.

Falcone, J., 2011: GAGES-II: Geospatial attributes of gages for evaluating streamflow. U.S. Geological Survey, accessed on 5 April 2015, https://water.usgs.gov/GIS/metadata/usgswrd/ XML/gagesII_Sept2011.xml\#stdorder. 
Fosu, B., S. S. Wang, and J. Yoon, 2016: The 2014/15 snowpack drought in Washington state and its climate forcing. Bull. Amer. Meteor. Soc., 97, S19-S24, https://doi.org/10.1175/ BAMS-D-16-0154.1.

Freund, R., and W. Wilson, 1998: Regression Analysis: Statistical Modeling of a Response Variable. Academic Press, 444 pp.

Gershunov, A., T. Shulgina, M. Ralph, D. Lavers, and J. Rutz, 2017: Assessing the climate-scale variability of atmospheric rivers affecting western North America. Geophys. Res. Lett., 44, 7900-7908, https://doi.org/10.1002/2017GL074175.

Glantz, M., 1982: Consequences and responsibilities in drought forecasting: The case of Yakima, 1977. Water Resour. Res., 18, 3-13, https://doi.org/10.1029/WR018i001p00003.

Gleick, P., 2016: Impact of California's five-year (2012-2016) drought on hydroelectricity. Tech. Rep., Pacific Institute, 16 pp., accessed 1 May 2017, https://pacinst.org/publication/impacts-californiasfive-year-2012-2016-drought-hydroelectricity-generation/.

Golladay, S., P. Gagnon, M. Kearns, J. Battle, and D. Hicks, 2004: Response of freshwater mussel assemblages (Bivalvia: Unionidae) to a record drought in the Gulf Coastal Plain of southwestern Georgia. J. N. Amer. Benthol. Soc., 23, 494-506, https://doi.org/ 10.1899/0887-3593(2004)023<0494:ROFMAB > 2.0.CO;2.

Harding, B., T. Sangoyomi, and E. Payton, 1995: Impacts of a severe sustained drought on Colorado River water resources. Water Resour. Bull., 31, 815-824, https://doi.org/10.1111/ j.1752-1688.1995.tb03403.x.

Harpold, A., M. Dettinger, and S. Rajagopal, 2017: Defining snow drought and why it matters. Eos, Trans. Amer. Geophys. Union, 98, https://doi.org/10.1029/2017EO068775.

Heim, R., 2002: A review of twentieth-century drought indices used in the United States. Bull. Amer. Meteor. Soc., 83, 1149-1165, https://doi.org/10.1175/1520-0477-83.8.1149.

Henn, B., A. Newman, B. Livneh, C. Daly, and J. Lundquist, 2018: An assessment of differences in gridded precipitation datasets in complex terrain. J. Hydrol., 556, 1205-1219, https://doi.org/ 10.1016/j.jhydrol.2017.03.008.

Koenker, R., S. Portnoy, P. Ng, A. Zeileis, P. Grosjean, and B. Ripley, 2018: quantreg: Quantile regression, version 5.3.4. R package, https://cran.r-project.org/web/packages/quantreg.

Konrad, C., T. Haluska, T. Olsen, D. Saleh, K. Watson, and J. Bartolino, 2018: Measures of the vulnerability of runoff to drought during 2015 in the western United States. U.S. Geological Survey data release, https://doi.org/10.5066/F7J67FD2.

Lake, P., 2003: Ecological effects of perturbation by drought in flowing waters. Freshwater Biol., 48, 1161-1172, https://doi.org/ 10.1046/j.1365-2427.2003.01086.x.

Mao, Y., B. Nijssen, and D. P. Lettenmaier, 2015: Is climate change implicated in the 2013-2014 California drought? A hydrologic perspective. Geophys. Res. Lett., 42, 2805-2813, https:// doi.org/10.1002/2015GL063456.

Marlier, M., M. Xiao, R. Engel, B. Livneh, J. Abatzoglou, and D. Lettenmaier, 2017: The 2015 drought in Washington state: A harbinger of things to come? Environ. Res. Lett., 12, 114008, https://doi.org/10.1088/1748-9326/aa8fde.

Milly, P., 1994: Climate, soil water storage, and the average annual water balance. Water Resour. Res., 30, 2143-2156, https:// doi.org/10.1029/94WR00586.

Mock, C., 1996: Climatic controls and spatial variations of precipitation in the western United States. J. Climate, 9, 1111-1125, https://doi.org/10.1175/1520-0442(1996)009<1111:CCASVO> 2.0.CO;2.

Mote, P., A. Hamlet, M. Clark, and D. Lettenmaier, 2005: Declining mountain snowpack in western North America. Bull.
Amer. Meteor. Soc., 86, 39-50, https://doi.org/10.1175/BAMS86-1-39.

and Coauthors, 2016: Perspectives on the causes of exceptionally low 2015 snowpack in the western United States. Geophys. Res. Lett., 43, 10 980-10 988, https://doi.org/10.1002/ 2016GL069965.

National Centers for Environmental Information, 2016: National Climate Report - Annual 2015. NOAA, accessed 5 April 2017, https://www.ncdc.noaa.gov/sotc/national/201513.

National Operational Hydrologic Remote Sensing Center, 2016: Snow Data Assimilation System (SNODAS) data products at NSIDC, version 1. National Snow and Ice Data Center, accessed 18 July 2016, https://doi.org/10.7265/N5TB14TC.

Newman, M., and Coauthors, 2016: The Pacific decadal oscillation, revisited. J. Climate, 29, 4399-4427, https://doi.org/10.1175/ JCLI-D-15-0508.1.

Overpeck, J., 2013: The challenge of hot drought. Nature, 503, 350-351, https://doi.org/10.1038/503350a.

PRISM Climate Group, 2016: PRISM Climate Data. Accessed 12 October 2016, http://www.prism.oregonstate.edu.

R Core Team, 2018: The R Stats Package version 3.4.3. R Foundation for Statistical Computing, https://cran.r-project.org.

Risbey, J., and D. Entekhabi, 1996: Observed Sacramento basin streamflow response to precipitation and temperature changes and its relevance to climate impact studies. J. Hydrol., 184, 209-223, https://doi.org/10.1016/0022-1694(95)02984-2.

Safeeq, M., G. Grant, S. Lewis, M. Kramer, and B. Staab, 2014: A hydrogeologic framework for characterizing summer streamflow sensitivity to climate warming in the Pacific Northwest, USA. Hydrol. Earth Syst. Sci., 18, 3693-3710, https://doi.org/ 10.5194/hess-18-3693-2014.

Sankarasubramanian, A., R. Vogel, and J. Limbrunner, 2001: Climate elasticity of streamflow in the United States. Water Resour. Res., 37, 1771-1781, https://doi.org/10.1029/2000WR900330.

Schaake, J., and L. Chunzhen, 1989: Development and application of simple water balance models to understand the relationship between climate and water resources. IAHS Publ., 181, 343-352.

Seager, R., M. Hoerling, S. Schubert, H. Wang, B. Lyon, A. Kumar, J. Nakamura, and N. Henderson, 2015: Causes of the 2011-14 California drought. J. Climate, 28, 6997-7024, https://doi.org/ 10.1175/JCLI-D-14-00860.1.

Seattle Public Utilities, 2006: Water Shortage Contingency Plan: Supplement to the Seattle Public Utilities 2007 Water System Plan. Tech. Rep., City of Seattle, Seattle, WA, accessed 5 April 2018, http://www.seattle.gov/util/cs/groups/public/@spu/@water/ documents/webcontent/WATERSHOR_200312021018123.pdf.

Solder, J., B. Stolp, V. Heilweil, and D. Susong, 2016: Characterization of mean transit time at large springs in the upper Colorado River basin, USA: A tool for assessing groundwater discharge vulnerability. Hydrogeol. J., 24, 2017-2033, https:// doi.org/10.1007/s10040-016-1440-9.

Stoelzle, M., K. Stahl, A. Morhard, and M. Weiler, 2014: Streamflow sensitivity to drought scenarios in catchments with different geology. Geophys. Res. Lett., 41, 6174-6183, https:// doi.org/10.1002/2014GL061344.

Turner, B., and Coauthors, 2003: A framework for vulnerability analysis in sustainability science. Proc. Natl. Acad. Sci. USA, 100, 8074-8079, https://doi.org/10.1073/pnas.1231335100.

U.S. Geological Survey, 2017: National Water Information System. USGS, accessed 24 January 2017, https://doi.org/10.5066/ F7P55KJN.

van Dijk, A., H. Beck, R. Crosbie, R. de Jeu, Y. Liu, G. Podger, B. Timbal, and N. Viney, 2013: The Millennium Drought in 
southeast Australia (2001-2009): Natural and human causes and implications for water resources, ecosystems, economy, and society. Water Resour. Res., 49, 1040-1057, https://doi.org/ 10.1002/wrcr.20123.

van Lanen, H., and Coauthors, 2016: Hydrology needed to manage droughts: The 2015 European case. Hydrol. Processes, 30, 3097-3104, https://doi.org/10.1002/hyp.10838.

Williams, A., R. Seager, J. T. Abatzoglou, B. I. Cook, J. E. Smerdon, and E. R. Cook, 2015: Contribution of anthropogenic warming to California drought during 2012-2014.
Geophys. Res. Lett., 42, 6819-6828, https://doi.org/10.1002/ 2015 GL064924.

Wood, E., S. Schubert, A. Wood, C. Peters-Lidard, K. Mo, A. Mariotti, and R. Pulwarty, 2015: Prospects for advancing drought understanding, monitoring, and prediction. J. Hydrometeor., 16, 1636-1657, https://doi.org/10.1175/JHM-D-14-0164.1.

Xia, Y., 2008: Adjustment of global precipitation data for orographic effects using observed annual streamflow and the $\mathrm{LaD}$ model. J. Geophys. Res., 113, D04106, https://doi.org/10.1029/ 2007JD008545. 